Magneto-optik (ohne Zeeman-Effekt)

(Handbuch der Experimentalphysik. Herausgegeben von W. Wien und F. Harms. Band 16, Teil 1.) Von Prof. Wilhelm Schütz. Pp. $x+378$. (Leipzig: Akademische Verlagsgesellschaft m.b.H., 1936.) 32 gold marks.

Prof. Schürtz has ably carried out the task of co-ordinating and discussing the numerous experimental and theoretical researches on magneto-optics published up to the early part of the year 1936. More than half the book is naturally concerned with the Faraday effect. Since the appearance of Voigt's account of magneto-optics in 1916, much experimental and theoretical work has been done, not only on the normal diamagnetic rotation but also on the selective diamagnetic, the paramagnetic and the ferromagnetic rotations, and a convincing account of these topics is given. An interesting summary of various theories of the Faraday effect begins with the classical electron theory and goes up to the quantum-mechanical theories of Rosenfeld for atoms, and of Serber for molecules. The section under the heading of the transverse magnetic double refraction of light directs attention to the Voigt effect, but is particularly devoted to the Cotton-Mouton effect, for Prof. Cotton's powerful electromagnet has enabled him and his collaborators to obtain and measure effects beyond the ken of other observers. It is interesting to note (p. 218) how the measurement of the transverse magnetic double refraction in nitro-benzol can serve as a measure of the efficiency of an electromagnet.

A third section deals with the magnetic double refraction and dichroism of colloidal suspensions (Majorana effect), and of coarse suspensions of powdered crystals in liquids. In addition to Cotton's work, that of Procopiu at Jassy, Rumania, is prominent here. Experimental work on the magnetooptic Kerr effect is considered under the headings of polar, meridional and equatorial Kerr effects. The Voigt and Snow theories linking up the Kerr and Faraday effects to various optical constants of metals are amply discussed. Adequate mention is made throughout of the researches carried out in various countries, and Prof. Schütz's own important work is modestly treated.

The term 'gauss' is still preferred to 'oersted' as the name of the unit of magnetic intensity, and the plane of the electric vector is called the plane of polarization. Apart from a few trifling mis-spellings of proper names, the book appears remarkably free from defects.

N. D

\section{Keris and other Malay Weapons}

By G. B. Gardner. Second edition. Pp. 138. (Singapore : Progressive Publishing Co. ; London : Bernard Quaritch, Ltd., 1936.) 6s. 6d.

ThE author provides a complete survey of the Keris, enumerating its parts, main types and processes of manufacture. His general classification is clear and convincing, and marks a distinct advance in the study of oriental arms; it will be of special use to museum curators. It is noteworthy that his defini- tions are given in detail and used consistently. It is now, therefore, possible to classify this interesting local weapon and to discuss its typology with an agreed terminology.

As to its origins, Mr. Gardner quotes the use of the ray sting [Ikan Pari] as a keris, and directs attention to the thumb and finger grip it demands. $\mathrm{He}$, also, follows Dr. van Stein Callenfels in his early dating (seventh century A.D.) for the all-metal, anthropomorphic keris Majapahit. Apart from this strange little weapon, the hilts of keris seem to fall into two main groups, based on a bird type and a demon type, both of which are found on the mainland, extending to the Shan area. Both these basic types, when over-foliated, would seem to merge in the well-known Madura 'flower'-hilt, which would, therefore, appear to be secondary. In any event, the keris Majapahit remains a little anomalous.

Mr. Gardner's notes upon keris magic are of special interest; sword magic has been somewhat neglected in the Orient, and is commoner than extant publications would suggest.

K. de B. C.

The Official Year-Book of the Scientific and Learned Societies of Great Britain and Ireland;

with a Record of Publications issued during the Session 1935-1936. Compiled from Official Sources. Fifty-third Annual Issue. Pp. vii + 170. (London: Charles Griffin and Co., Ltd., I936.) 10s. net.

THE fifty-third annual issue of this year-book maintains the high standing that its predecessors have achieved, thus making it an indispensable guide in scientific, technical and other libraries, laboratories, universities, research institutions, etc. The learned societies are classified under fifteen headings, and this, together with a very full index, makes reference a very easy task. Under each society, association, ete., are given the list of officers, details of membership, arrangements for meetings, titles of publications, etc. The fact that all this information is gleaned from official sources makes the volume authoritative and one which is almost unique among the annual publications of reference literature.

\section{Reactions of the Human Machine}

By John Yerbury Dent. Pp. 288. (London: Victor Gollancz, Ltd., 1936.) 8s. 6d. net.

THE author of this lively and well-written book, besides being a medical practitioner, is quite clear that a doctor should also be something of a psychologist. The type of psychology which appeals to him is sufficiently indicated by the title. He has no use for "the older subjective language" which includes words like sensation, consciousness and will. Equally little use has he for the psycho-analytic libido and censor. He sees nothing in the "human machine" except the structure of the organism and its responses to environment. Few psychologists will agree with him ; but his method of psyehological approach has not prevented him from writing an extremely good book on its own lines, quite intelligible to the layman, and useful also to medical men. 